\title{
ТЕОРЕТИКО-МЕТОДОЛОГІЧНІ ЗАСАДИ ЕМПІРИЧНОГО ДОСЛІДЖЕННЯ ДОВІРИ ДО СЕБЕ
}

\begin{abstract}
Анотація. У статті обгрунтовано теоретико-методологічні засади емпіричного дослідження довіри до себе. У якості теоретико-методологічних засад розглядаються розуміння довіри до себе в контексті сучасних наукових розвідок й методика організації та проведення їі емпіричного дослідження. Узагальнено й систематизовано сучасні наукові погляди вітчизняних і зарубіжних учених на психологічний зміст і структуру довіри до себе, проаналізовано індивідуально-психологічні чинники ії детермінації. Представлено визначення й авторську структурну модель довіри до себе в інтеграції з її індивідуально-психологічними чинниками, завдяки якій можливо операціоналізувати базові діагностичні індикатори емпіричного дослідження. Зазначено, що розроблена структурна модель довіри до себе може виступати надійним підгрунтям для проведення емпіричного дослідження й налагодження в подальшому психологічного супроводу ïi розвитку у процесі цілеспрямованого формувального впливу.
\end{abstract}

Ключові слова: довіра до себе, індивідуально-психологічні чинники, структурна модель довіри до себе, теоретико-методологічні засади, емпіричне дослідження, психологічний супровід.

\section{Kolomiiets Lesia, Kozhedub Tetiana, Huk Kateryna \\ Vinnytsia Mykhailo Kotsiubynskyi State Pedagogical University}

\section{THEORETICAL AND METHODOLOGICAL PRINCIPLES OF SELF-CONFIDENCE'S EMPIRICAL STUDY}

Summary. Theoretical and methodological principles of self-confidence's empirical study were substantiated in the article. Theoretical and methodological principles are understanding of self-confidence in the context of modern scientific research and methods of organizing and conducting its empirical research. Modern scientific views of domestic and foreign scientists on the psychological content and structure of self-confidence were generalized and systematized. The individual and psychological factors of determination of self-confidence's structure were analyzed. It was found that the concept "self-confidence" harmoniously combined with other types of trust, such as trust in the environment, trust in the world. It was found that scientists reveal the concept "self-confidence" through achieving subjectivity, personal maturity, focus on self-development and self-realization. The structural model of self-confidence in integration with its individual psychological factors (personal identity, viability, psychological well-being, confidence etc.) was presented. The structural model of self-confidence is a solid basis for empirical research and further establishment of psychological support for its development in the process of purposeful formative influence. The functions, components, levels and individual psychological factors of structural model of self-confidence were defined. It is noted that the theoretical model needs empirical verification. Methodological bases of empirical research of self-confidence were substantiated. It is determined that the high level of validity of the empirical study of self-confidence will ensure its planning and implementation on the basis of systematic and operational approaches. It is determined that adequate selection of empirical methods, allows to reveal the level of self-confidence and its individual psychological factors, as well as to determine the understanding of self-confidence by subjects of different ages

Keywords: self-confidence, individual and psychological factors, structural model of self-confidence, theoretical and methodological principles, empirical research, psychological support.

$\Pi$ остановка проблеми. Сучасні швидкоплинні умови життедіяльності людини часто провокують появу ситуацій, в яких виникає необхідність долати труднощі й відповідати на різнопланові виклики, проявляти готовність підтримувати високий рівень самоефективності в діяльності, спілкуванні й соціальній взаемодії, забезпечувати успішність самореалізації. Це стае можливим завдяки особистісним якостям, що підвищують віру особистості у власні сили й можливості, вселяють впевненість у здатності досягати різні життеві цілі, покладаючись на себе, приймаючи повною мірою своє «Я». Однією з таких особистісних якостей $є$ довіра до себе.

Довіра до себе вселяе суб’екту переконаність щодо сили особистісних ресурсів, стимулюе готовність наполегливо працювати 3 певним ризи- ком для досягнення мети, стабілізуе самооцінку й рівень домагань, дозволяе вибудовувати стратегію власної життедіяльності. Високий рівень довіри до себе символізуе переживання особистістю стану внутрішньої гармонії, психологічного благополуччя, самоприйняття, орієнтованість на життеві звершення, досягнення успіху, оптимістичну налаштованість щодо життя. Навпаки, низький рівень довіри до себе супроводжуеться невпевненістю, нерозумінням себе й власних потреб, неадекватною самооцінкою, переживанням внутрішньоособистісного конфлікту, острахом труднощів і невдач, невмінням користуватися власними особистісними ресурсами, що дезінтегруе «Я», погіршуе адаптованість, знижуе відчуття задоволеності життям, негативно позначаеться на встановленні соціальних контактів. 
Аналіз останніх досліджень і публікацій. Актуалізацію аспектів проблеми довіри, довіри до себе знаходимо в науковому доробку зарубіжних (С. Джурард, П. Ласкоу, Е. Еріксон, К. Роджерс, Ф. Перлз, А. Селігман, Ф. Фукуяма, Е. Шостром та ін.) і російських (I. Антоненко, Б. Астаніна, В. Зінченко, А. Купрейченко, М. Клементьєва, Т. Скрипкіна та ін.) учених. В українській психології вивченням проблеми довіри до себе щодо осіб різного віку опікувалися Д. Анпілова, Н. Василець, Н. Срмакова, Н. Кравець, В. Кравченко, С. Шевченко та ін.

Виділення невирішених раніше частин загальної проблеми. Наукова увага до проблеми довіри до себе виправдана з огляду на необхідність розроблення дієвих шляхів налагодження психологічного супроводу розвитку довіри до себе на різних етапах онтогенезу. Це вимагає узагальнення й систематизації наявних наукових поглядів на психологічний зміст і структуру ціеї якості, організації й реалізації емпіричного дослідження її детермінації.

Мета статті - обтрунтувати теоретико-методологічні засади емпіричного дослідження довіри до себе.

Виклад основного матеріалу дослідження. У сучасних джерелах довіра до себе визнаеться багатоаспектною психічною якістю, що мае виражену динаміку, відзначаеться багатокомпонентністю розгляду, вимагає відстеження специфічних корелятів [2; 7; 13; 14 та ін.]. Тому, на нашу думку, потребують обгрунтування теоретико-методологічні засади, що виступатимуть надійним підгрунтям емпіричного дослідження довіри до себе й подальшого психологічного супроводу їі розвитку у процесі цілеспрямованого формувального впливу. У контексті досліджуваної нами проблеми під теоретико-методологічними засадами розуміемо узагальнення з приводу психологічного змісту й структури довіри до себе, їі індивідуально-психологічних чинників, що представлені в наукових публікаціях сучасних вітчизняних і зарубіжних науковців, а також методику організації та проведення емпіричного дослідження довіри до себе. Обгрунтуємо по черзі теоретичні й методологічні засади дослідження.

Аналіз наукових джерел показуе, що довіра до себе категоризуеться вченими по-різному: як особистісне утворення, рефлексивний суб’ектний феномен, прагнення, стан, почуття, здібність, ставлення, гіпотетичний конструкт тощо. Це засвідчуе наявність розмаїтих наукових поглядів на визначення довіри до себе, її психологічної сутності, походження й проявів. Зокрема, довіру до себе науковці визначають таким чином:

- здібність, що впливае на саморозкриття (С. Джурард, А. Маслоу);

- прагнення особистості віднайти джерела підтримки у власному «Я» (Ф. Перлз, Е. Шостром);

- прийняття суб'ективного життевого досвіду, прояви інтуїції, творчості, уміння прислухатися до свого «Я», почуття автентичності (К. Роджерс);

- базова умова успішної самореалізації особистості в повсякденні, в міжособистісних стосунках, у масштабах життевого шляху; баланс суверенності психологічного простору й взаємодії зі світом (Н. Астаніна);
- ставлення до власної суб'єктності, розуміння іï̈ значущості у плані гармонізації «Я», свого внутрішнього світу (Т. Пухарева);

- рефрлексивний, суб'єктний феномен, завдяки якому особистість мае можливість займати ціннісну позицію щодо себе, оточення й стратегію власного життя, що не суперечить особистісним смислам й зв'язуе життя у єдиний процес життедіяльності у континуумі «минуле - теперішне - майбутне» (Т. Скрипкіна);

- цілісне багатоаспектне утворення особистості, що позначаеться на самоорганізації й самореалізації майбутніх психологів у сфері міжособистісної взаємодії і в процесі реалізації профессійних функщій (С. Шевченко) та ін. [2; 3; 8; 10; 13; 14].

$\mathrm{y}$ контексті нашого наукового пошуку варто зробити акцент на тому, що науковці представили також авторські погляди на структуру довіри до себе як системного утворення, виділивши такі ключові складові:

- фрункції: інтеграції минулого, сьогодення й майбутнього, забезпечення зв'язку людини зі світом, ефекту цілісності особистості та її буття, відповідності поведінки ухваленим рішенням, поставленим цілям і завданням (Т. Скрипкіна); пізнання і самопізнання, самоорганізації, взаємодії зі світом і захисту від небажаного впливу, самовизначення, психологічного полегшення через саморозкриття, оптимізації соціальної взаємодії тощо (А. Купрейченко, С. Табхарова); психологічного розвантаження, зворотного зв'язку в процесі самопізнання, психологічного зближення і поглиблення взаємостосунків (В. Сафоонов);

- компоненти: когнітивний, афективний, поведінковий (Н. Єрмакова, Т. Скрипкіна); когнітивний, мотиваційний, емоційний, поведінковий, рефлексивний (С. Шевченко);

- рівні (високий, середній, низький, або довіра до себе - недовіра до себе) [4, с. $117 ; 10$, с. 58 ; 14 , c. 50-57].

у наукових публікаціях Т. Скрипкіної, зокрема, довіра до себе характеризуеться з точки зору досягнення цілісності й особистісної зрілості. Учена констатуе, що довіра до себе властива саме зрілій особистості, яка здатна брати на себе відповідальність за зміст, вчинки, події та спрямування власної життедіяльності. Відповідно, у структурі довіри до себе Т. Скрипкіна виділяе такі змінні: активуюча («Я хочу», тобто потреби, прагнення, інтереси особистості), прогностична («Я можу» як можливості суб’єкта задовольнити свої потреби, прагнення) і ціннісно-смислова («Я повинен», що реалізуе функцію оцінювання життедіяльності з точки зору відповідності особистісним смислам, переконанням, світоглядним засадам та зовнішнім умовам суб'ектної активності особистості тощо) [13].

Схожі висновки щодо сутності довіри до себе робить С. Летягіна, як і більшість науковців наголошуючи на інтеграції довіри до себе, довіри до оточення й довіри до світу. Науковець вказуе, що довіра до себе базуеться на узагальненому й усвідомленому внутрішньому досвіді, що акумулюе знання, мораль, норми, цінності тощо. Недовіра до себе призводить до втрати індивідуальності, надмірної зосередженості на зовнішніх умовах, оцінках, підкріпленнях, що перешкоджае можливості досягнення цілісності «Я», особистіс- 
ної зрілості [11, с. 216]. На думку С. Летягіної, рівень довіри особистості до себе визначається такими чинниками: усвідомлення власних потреб, бажань, інтересів тощо; розуміння власних можливостей; збалансоване співвідношення потреб, особистісних можливостей їх задовольнити з власними ціннісно-смисловими утвореннями.

Теоретичний аналіз джерел показав розгляд окремими науковцями чинників детермінації довіри до себе. Зокрема, I. Антоненко, намагаючись визначити стратегію пояснення особистісної довіри, вказала на потребу враховувати такі чотири ключові фрактори: суб'єктні (постійні та тимчасові особистісні особливості суб'єкта довіри, рівень його базальної довіри); об'єктні (певні зовнішні/внутрішні, постійні/тимчасові, атрибутивні/випадкові характеристики об'єкта довіри, щодо яких довіра буде проявлятися певною мірою); середовищні (постійні або довготривалі впливи умов середовища, що позначаються на рівні довіри); ситуаційні (дія зовнішніх чинників у конкретній ситуації довіри) [14, с. 48-49].

У наукових публікащіях I. Кона, С. Пантилеєва, В. Століна та ін. пояснюеться взаємозв'язок довіри до себе й самоставлення особистості. Учені наголошують на високій інтеграції довіри до себе й компонентів самоставлення (саморозуміння, самоприйняття, самосхвалення, самоповага тощо), що в сукупності позначається на успішності самореалізації суб'єкта життедіяльності [12, с. 92]. С. Пантилєевим довіра до себе розглядається як емоційне почуття прихильності до власного «Я», відкритості й чесності щодо себе й переживання аутосимпатії. I. Кон уважав довіру до себе мотиваційним чинником ініціативності й самостійності особистості, порівнював її з почуттям власної гідності й самоповаги. В. Дорофреев співвідносив довіру до себе з усвідомленням власної самоцінності та самоприйняттям, що стимулюють аутосимпатію й самоприхильність і позначаються на якості «довірчого простору» [5, с. 244-245]. При відсутності довіри до себе, неприйнятті власних особливостей, самознецінюванні з'являеться т.зв. компенсаторний нереалістичний образ «Я», що неконструктивним чином позначається на життедіяльності особистості, перешкоджає її гармонійному саморозвитку.

Як феномен самосвідомості довіру особистості до себе визначила Н. Єрмакова, зазначаючи що вона проявляеться як самоставлення в когнітивній, емоційній і поведінковій сорерах, детермінуе єдність та інтегрованість «Я» [5, с. 246]. Зауважимо, що у наукових публікаціях Т. Скрипкіної також було доведено взаємодетермінацію довіри до себе й складових самоставлення (самоприйняття, самовпевненість, самоуправління) й самоактуалізації особистості (компетентність в часі, здатність до підтримки, ціннісні орієнтації, спонтанність поведінки тощо) [11].

У дослідженнях вчених робиться акцент на поясненні взаємозв'язку довіри до себе 3 такими психологічними якостями як віра в себе, впевненість у собі, самоефективність (I. Антоненко, Н. Василець, Н. Срмакова, В. Зінченко, Н. Кравець, Т. Скрипкіна та ін.). Віра в себе, впевненість у власній спроможності як суб'екта життедіяльності дозволяють особистості прийняти «Я» в своєрідності й неповторності, зрозуміти своє призначення, пізнати власну сутність у різних умовах середовища (навіть доволі нестабільних) $[14$, c. 35]. Втрата віри у себе, що може бути й наслідком досвіду попередньої взаємодії зі світом, спричиняе дестабілізацію самооцінки й самоставлення, появу відчуття меншовартості, слабкості «Я» $[6$, с. 74$]$.

Зауважимо, що Н. Василець, називаючи довіру до себе важливою умовою особистісної життедіяльності, висловлюе думку, що довіра й упевненість в собі не $є$ тотожними поняттями. Довіра до себе співвідноситься більше зі сподіваннями, очікуваннями позитивних результатів життєдіяльності у ситуаціях невизначеності повсякдення [4, с. 116]. Довіра до себе задовольняе суб'єктивні потреби особистості, що підвищуе відчуття соціального і психологічного благополуччя, і навпаки, соціальне і психологічне благополуччя підсилюють довіру до себе [4, с. 117].

У публікації Н. Кравець довіра співвідноситься з самоатрибуцією, тобто переконаністю у власних можливостях, якостях, самоефективності. Автор наголошуе, що важливу роль мають також самооцінка й рівень домагань, що впливають на уявлення особистості про власні можливості та знання про себе [8, с. 205]. Н. Кравець довіру до себе визнає передумовою повноцінного самовладання, розуміння своєї сутності, самоорганізації й самоактуалізації особистості. Все це в сукупності забезпечуе цілісність їі буття, виступає засобом гармонізації стосунків «Я» та «Я і світ» [8, с. 207]. У якості чинників довіри до себе як механізму суб'єктності особистості, Н. Кравець пропонуе вважати незалежність, спрямованість на досягнення успіху, усвідомлення самоцінності, здатність використовувати суб'єктивний досвід для майбутніх звершень, гармонійність поєднання довіри до себе і довіри до світу.

Окремий акцент на рефрлексивності, як індивідуально-психологічному чиннику довіри до себе, зробили М. Клементьева, Т. Скрипкіна та ін. М. Клементьєва, зокрема, розглядала довіру до себе в контексті екзистенціального досвіду. Довіра до себе тлумачиться дослідницею з точки зору самооцінювання, роздумів про себе, уваги до себе, прийняття власної щінності, що підсилюе «Я» особистості й робить їі більш готовою до діалогу з іншими [11, с. 106]. У контексті таких висновків М. Клементьева пропонуе для оцінювання особливостей довіри до себе використовувати біографрічну рефлексію - рефлексію життевого шляху (суб'єкт довіряє собі) і свого життєвого досвіду (субект не довіряе собі).

Т. Скрипкіна, власне, визначила довіру як рефлексивний, суб'єктний особистісний френомен, вважаючи, що довіра наділена досить високою редрлексивною здатністю, що дає особистості змогу будувати життевий шлях виходячи 3 ціннісного ставлення до себе, перетворюватися в автономного суверенного суб'єкта активності, здатного до самостійної постановки цілей та їх досягнення [13, с. 139]. Т. Скрипкіна також запропонувала типологію співвідношення стратегій поведінки особистості в залежності від довіри до себе і довіри до світу, що позначаються на їі самореалізації. У рівноважене співвідношення довіри до себе і довіри до світу забезпечує відносну стійкість діяльності особистості; домінування 
довіри до світу лежить в основі адаптації до середовища; переважання довіри до себе може супроводжуватися проявами неадаптивних форм активності через надміру виражений самостійний характер діяльності; відсутність довіри до світу пов'язана 3 втратою довіри до себе. Загалом, Т. Скрипкіна наголосила, що співвідношення довіри до світу і довіри до себе має бути гармонійним, інакше особистість буде схильна або до необачного ризику, або до повного відчуження від власного «Я».

Співзвучними є висновки української дослідниці Д. Анпілової, яка доводить, що довіра до себе базується на відчутті автентичності, пошуку джерела підтримки у власному «Я» й пов'язана 3 підсиленням особистісних можливостей, життетворчості, відповідальності за власне життя, а отже й адаптаційного потенціалу [1, с. 36].

Вважаємо доцільним згадати, що в дисертащійному дослідженні С. Шевченко стосовно осіб юнацького віку (майбутніх психологів) базова довіра до себе (за Е. Еріксоном) розглядається першоосновою, на якій з віком розвиваються в едності довіра до себе, довіра до світу й довіра до інших [14, с. 52]. Однією з умов розвитку довіри до себе С. Шевченко називає життездатність, яка покладається на самоедекктивність, наполегливість, внутрішній локус контролю, адаптащійні ресурси й стратегії подолання. Водночас В. Кравченко пропонує розгляда- ти життестійкість особистості як чинник довіри до себе в осіб юнацького віку [9, с. 139].

Зважаючи на проведений теоретичний аналіз сучасних наукових публікацій 3 проблеми довіри до себе, вважаємо можливим запропонувати авторське визначення й структурну модель довіри до себе, що виступатиме надійним підгрунтям для проведення в подальшому емпіричного дослідження й налагодження психологічного супроводу її розвитку у процесі цілеспрямованого форомувального впливу. Довіру до себе варто розуміти як динамічне, багатокомпонентне особистісне утворення, що відображає міру зрілості, цілісності й інтегрованості «Я», залежить від особливостей саморозуміння й самоприйняття, сорормованості психологічних ресурсів, детермінує можливості життевого самоздійснення, позначається на успішності соціальної взаємодії.

Сдрормульоване визначення є висхідним для створення структурної моделі довіри до себе в інтеграції з їі індивідуально-психологічними чинниками (див. рис. 1).

Усі компоненти структурної моделі довіри до себе є взаємопов'язаними елементами системи, що перебуває в динамічному стані як на рівні психічної організації «Я», так і на соціальному рівні «Я - інші». Зауважимо, що виділені нами функції довіри до себе (інтеграційна, реgблексивна, мотивуюча, адаптуюча, салоорганізуюча)

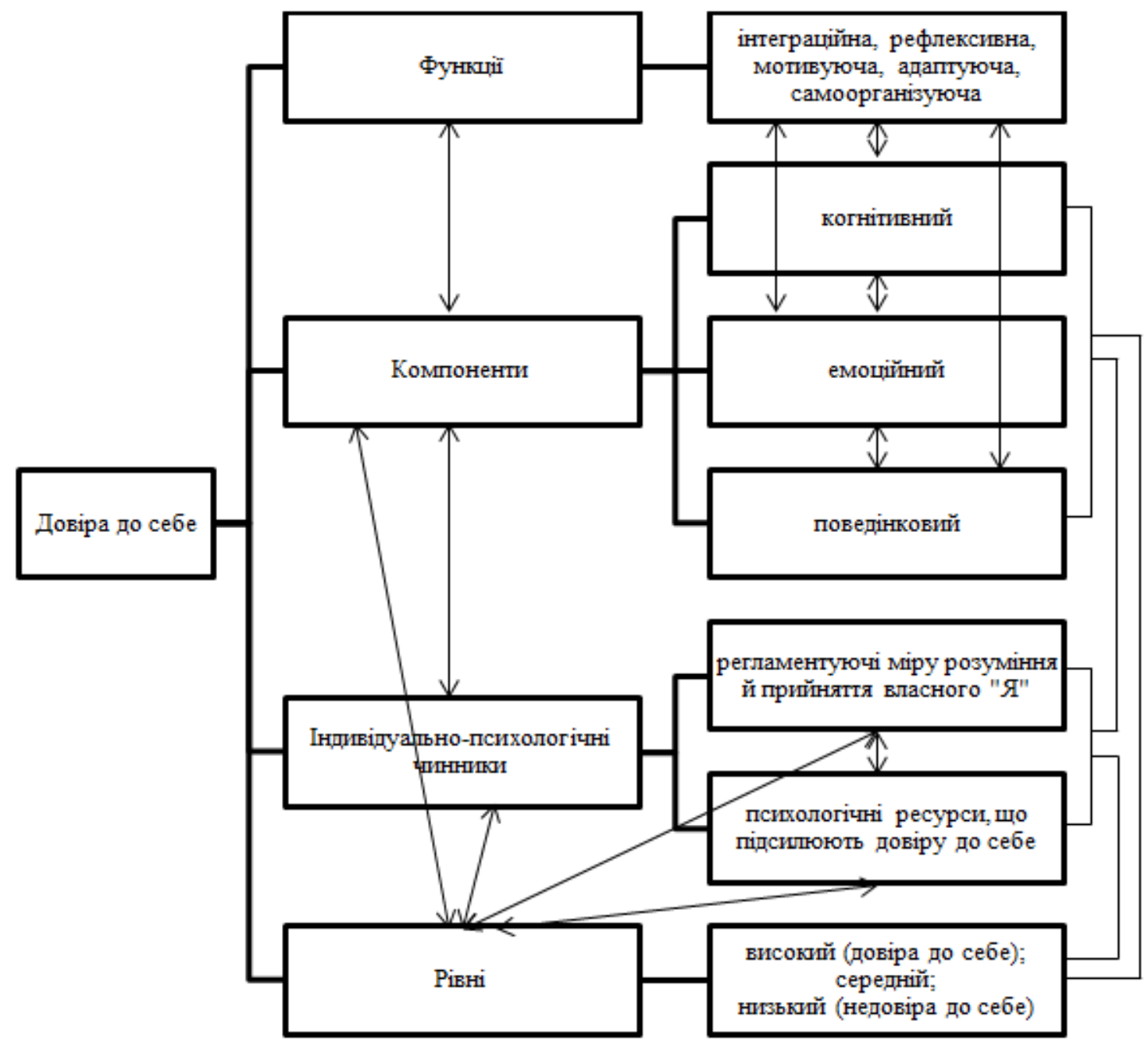

Рис. 1. Структурна модель довіри до себе 
дозволяють подивитися на це особистісне утворення 3 точки зору розвитку та реалізації суб'єктного потенціалу й особистісної активності. В якості компонентів довіри до себе нами визначено когнітивний (знання про себе й саморозуміння, критична й адекватна оцінка своїх здібностей і можливостей, усвідомлення власної самоцінності, вміння будувати «довірчий простір» щодо інших з використанням суб'єктивного досвіду); емоційний (ставлення до себе в сукупності сильних і слабких сторін, самоприйняття, переживання значущості суб'єктивного досвіду й можливостей його інтеграції для гармонізації довіри до себе й довіри до інших); поведінковий (конкретні наміри, дії, стратегії поведінки щодо власного «Я» і оточення, цілепокладання, самоконтроль, саморегуляція, самоорганізація, саморозвиток з урахуванням особистісних смислів й вимог соціальної спільноти).

3 урахуванням проведеного теоретичного аналізу, не претендуючи на вичерпне розуміння детермінащії довіри до себе, вважаємо, що рівень довіри до себе (високий, середній, низький) залежить від міри сорормованості й прояву в життедіяльності особистості індивідуально-психологічних чинників. Індивідуально-психологічні чинники довіри до себе ми умовно класифікували на такі дві групи: чинники, що регламентують міру розуміння й прийняття власного «Я» (салоставлення, ребблексія, екзистенційна здійсненність, особистісна ідентичність) й психологічні ресурси, що підсилюють довіру до себе (життєстійкість, життездатність, психологічне благополуччя, суб’єктивний локус контролю, впевненість у собі, салоеббективність).

Якщо робити акцент на методологічні засади емпіричного дослідження довіри до себе, то варто наголосити, що ми трактуємо їх більше у вузькому значенні з позицій сукупності доцільних етапів, підходів, принципів, методів, тобто з точки зору методики проведення конкретного психологічного дослідження. Вважаємо, що високий рівень валідності емпіричного дослідження довіри до себе забезпечать такі визначені методологічні засади:

1) вивчення довіри до себе та їі індивідуально-психологічних чинників здійснюватиметься для констатації їі рівня в осіб конкретного вікового періоду та з метою перевірки базової емпіричної гіпотези про взаємозв'язок довіри до себе та виокремлених індивідуально-психологічних чинників; перевірка едективності програми психологічного супроводу розвитку довіри до себе передбачає реалізацію формувального етапу експерименту;

2) планування й проведення емпіричного дослідження має відбуватися з урахуванням ключових позицій системного й діяльнісного підхо$\partial i s$, що дозволить розкрити психологічний зміст і структуру довіри до себе не лише як сукупність окремих компонентів, але й у дрорматі їх тісної взаємодії, взаємозумовленості, впорядкованості, цілісності, у контексті єдності внутрішньої і зовнішньої психічної діяльності особистості;

3) підготовка й реалізація дослідження передбачає урахування загальнонаукових (системного, моделювання), спеціально наукових (детермінізму, відображення, єдності психіки i діяльності, розвитку, системно-структурного; побудови дослідження в рамках наукової парадигми, об'єктності, надійності, репрезентативності, інструментальної адекватності) і спеuифбічних принципів дослідження довіри до себе (врахування вікових особливостей, інтеграції інтрапсихічного і соціального, комбінування суб'єктивних і об'єктивних емпіричних підходів, рефрлексивної зумовленості тощо);

4) досягненню визначеної мети, реалізації сорормульованих завдань дослідження на констатувальному й формувальному етапах сприятимуть дібрані методи дослідження (теоретичні, емпіричні, обробки й інтерпретації одержаних даних, практичного психологічного впливу); добір, зокрема, емпіричних методів має відбуватися 3 комбінуванням суб'єктивного й об’єктивного підходів; доречним $є$ вивчення особистісної семантики довіри до себе, притаманної досліджуваним різного віку.

Висновки i перспективи подальших досліджень. Проведений теоретичний аналіз наукових публікацій підтвердив важливість розроблення проблеми довіри до себе. Перспективи їі подальшого вивчення вбачаємо, зокрема, в проведенні емпіричного дослідження довіри до себе осіб різного віку, характеристиці їі особливостей, чинників детермінації з метою верифікації запропонованої структурної моделі; розробленні й апробації програми психологічного супроводу розвитку довіри до себе.

\section{Список літератури:}

1. Анпілова Д.В. Психологічне значення довіри для самоактуалізації особистості в період ранньої дорослості : Збірник наукових праць К-ПНУ ілені Івана Огієнка, Інституту психологї ілені Г.С. Костюка НАПН Украӥни. 2016. Вип. 33. С. 34-46.

2. Антоненко И.В. Социальная психология доверия : дис. ... докт. психол. наук : спец. $19.00 .05-$ социальная психология. Ярославль, 2006. 498 с.

3. Астанина Н.Б. Особенности доверия себе у несовершеннолетних правонарушителей мужского пола. Личность в современнол обществе: психологические проблель и перспективы развития : сборник научных трудов. Воронеж : Издательско-полиграфический центр Воронежского государственного университета, 2013. T. 3. C. $328-331$.

4. Василець Н.М. Довіра як підгрунтя толерантності у психолого-педагогічній взаємодії. Науковий вісник Львівського державного університету внутрішніх справ. 2012. № 1. С. 114-121.

5. Єрмакова Н.О. Довіра до себе як особистісна детермінанта профресійного зростання студентів юнацького віку. Вісник післядипломної освіти. 2012. Вип. 6. С. 241-249.

6. Єсип М.З., Михайлюк І.В. Схильність до девіантної поведінки підлітків з низьким рівнем довіри до себе. Психологія і особистість. 2016. № 2(10). Ч. 1. С. 71-82.

7. Зинченко В.П. Психология доверия. Самара : Издательство СИОКПП, 2001. 104 с.

8. Кравець Н.М. Довіра до себе - суб'ективний феномен особистості. Наукові студії із соціальної та політичної психологї̈. 2011. Вип. 26. С. 201-208. 
9. Кравченко В.Ю. Довіра до себе у вимірі життестійкості особистості в юнацькому віці. Молодий вчений. 2015. № 3. Вип. 18. С. 138-141.

10. Купрейченко А.Б., Табхарова С.П. Критерии доверия и недоверия личности другим людям. Психологический журнал. 2007. Т. 28. № 2. С. 55-67.

11. Психология общения и доверия: теория и практика : Сборник материалов Международной конференции УРАО, ПИ РАО, МГУ. 6-7 ноября 2014 г. / Под ред. Т.П. Скрипкиной. Москва : Университет РАО, 2014.777 с.

12. Пухарева Т.С. Особенности доверия к себе и к другому у студентов юридического факультета : дис. ... канд. психол. наук : спец. 19.00.07 - педагогическая психология. Ростов н/Д, 2011. 160 с.

13. Скрипкина Т.П. Психология доверия : Учеб. пособие для студ. высш. пед. учеб. заведений / Под ред. М. Сластенина. Москва : Академия, 2000. 264 с.

14. Шевченко С.В. Психологічні особливості довіри до себе у майбутніх психологів : дис. ... канд. психол. наук : 19.00.07 - педагогічна та вікова психологія. Київ, 2018. 260 с.

\section{References:}

1. Anpilova D.V. (2016) Psykholohichne znachennia doviry dlia samoaktualizatsii osobystosti v period rannoi doroslosti [Psychological significance of trust for self-actualization of personality in early adulthood]: Zbirnyk naukovykh prats K-PNU imeni Ivana Ohiienka, Instytutu psykholohii imeni H.S. Kostiuka NAPN Ukrainy, vol. 33, pp. 34-46.

2. Antonenko Y.V. (2006) Sotsyalnaia psykholohyia doveryia [Social psychology of trust]: dys. ... dokt. psykhol. nauk: spets. 19.00.05 - sotsyalnaia psykholohyia. Yaroslavl, 498 p.

3. Astanyna N.B. (2013) Osobennosty doveryia sebe u nesovershennoletnykh pravonarushytelei muzhskoho pola [Features of self-confidence among juvenile male offenders]. Lychnost $v$ sovremennom obshchestve: psykholohycheskye problemy y perspektyvy razvytyia: sbornyk nauchnykh trudov. Voronezh: Yzdatelskopolyhrafycheskyi tsentr Voronezhskoho hosudarstvennoho unyversyteta, t. 3, pp. 328-331.

4. Vasylets N.M. (2012) Dovira yak pidgruntia tolerantnosti u psykholoho-pedahohichnii vzaiemodii [Trust as a basis for tolerance in psychological and pedagogical interaction]. Naukovyi visnyk Lvivskoho derzhavnoho universytetu vnutrishnikh sprav, no. 1, pp. 114-121.

5. Iermakova N.O. (2012) Dovira do sebe yak osobystisna determinanta profesiinoho zrostannia studentiv yunatskoho viku [Self-confidence as a personal determinant of professional growth of young students]. Visnyk pisliadyplomnoi osvity, vol. 6 , pp. 241-249.

6. Iesyp M.Z., Mykhailiuk I.V. (2016) Skhylnist do deviantnoi povedinky pidlitkiv z nyzkym rivnem doviry do sebe [Predisposition to deviant behavior of adolescents with low self-esteem]. Psykholohiia $i$ osobystist, no. 2(10), ch. 1, pp. 71-82.

7. Zynchenko V.P. (2001) Psykholohyia doveryia [The psychology of trust]. Samara: Yzdatelstvo SYOKPP, 104 p.

8. Kravets N.M. (2011) Dovira do sebe-subiektyvnyi fenomen osobystosti [Self-confidence is a subjective phenomenon of personality]. Naukovi studii iz sotsialnoi ta politychnoi psykholohii, vol. 26, pp. 201-208.

9. Kravchenko V.Yu. (2015) Dovira do sebe u vymiri zhyttiestiikosti osobystosti v yunatskomu vitsi [Self-confidence in measuring the vitality of the individual in adolescence]. Molodyi vchenyi, no. 3, vol. 18, pp. 138-141.

10. Kupreichenko A.B., Tabkharova S.P. (2007) Kryteryy doveryia y nedoveryia lychnosty druhym liudiam [Criteria for trust and distrust of a person in other people]. Psykholohycheskyi zhurnal, t. 28, no. 2, pp. 55-67.

11. Psykholohyia obshchenyia y doveryia: teoryia y praktyka [Psychology of communication and trust: theory and practice]: Sbornyk materyalov Mezhdunarodnoi konferentsyy URAO, PY RAO, MHU. 6-7 noiabria 2014 h. $/$ Pod red. T.P. Skrypkynoi. Moskva: Unyversytet RAO, 2014. 777 p.

12. Pukhareva T.S. (2011) Osobennosty doveryia $\mathrm{k}$ sebe y $\mathrm{k}$ druhomu $\mathrm{u}$ studentov yurydycheskoho fakulteta [Features of trust in oneself and in others among law students]: dys. ... kand. psykhol. nauk: spets. 19.00 .07 pedahohycheskaia psykholohyia. Rostov n/D, $160 \mathrm{p}$.

13. Skrypkyna T.P. (2000) Psykholohyia doveryia [The psychology of trust]: Ucheb. posobye dlia stud. vyssh. ped. ucheb. zavedenyi / Pod red. M. Slastenyna. Moskva: Akademyia, 264 p.

14. Shevchenko S.V. (2018) Psykholohichni osoblyvosti doviry do sebe u maibutnikh psykholohiv [Psychological features of self-confidence in future psychologists]: dys. ... kand. psykhol. nauk: 19.00.07 - pedahohichna ta vikova psykholohiia. Kyiv, 260 p. 